\title{
Protracted Febrile Myalgia Syndrome: A Case Report Focusing on Possible Environmental Triggers
}

\author{
Uzamış Febril Miyalji Sendromu: Muhtemel Çevresel Tetikleyicilere Odaklanan Bir Olgu \\ Sunumu
}

\author{
Mahmut ALPAYCI, ${ }^{1}$ Arda KANDEMİR, ${ }^{1}$ Mehmet KORKMAZ ${ }^{2}$ \\ ${ }^{1}$ Department of Physical Medicine and Rehabilitation, Bitlis State Hospital, Bitlis, Turkey \\ ${ }^{2}$ Department of General Surgery, Bitlis State Hospital, Bitlis, Turkey
}

Protracted febrile myalgia syndrome (PFMS) is an uncommon, dramatic manifestation of familial Mediterranean fever (FMF) which is characterized by severe myalgia and high fever. This syndrome is considered to be either a rare type of vasculitis requiring corticosteroid treatment or an extension of the inflammation in FMF which is associated with Mediterranean fever (MEFV) gene mutations. Although the exact environmental triggers for the syndrome are unknown, various factors, such as streptococcal infections, have been suggested. In this article, we present a 33-yearold male patient who developed PFMS after a long-term travel and hyperthermal $\left(>40{ }^{\circ} \mathrm{C}\right)$ balneotherapy. To the best of our knowledge, this is the first case report which proposes a relationship between PFMS and balneotherapy.

Key words: Balneotherapy; fever; myalgia.

Protracted febrile myalgia syndrome (PFMS) is a rare, dramatic manifestation of familial Mediterranean fever $(\mathrm{FMF})^{[1]}$ and is considered to be either an extension of the inflammation associated with FMF or a rare type of vasculitis associated with the same this disease which is characterized by severe paralyzing myalgia of the upper and lower extremities, high fever, normal creatine kinase, and elevated acute phase reactants. ${ }^{[2]}$ A striking feature of PFMS is that the symptoms respond very effectively
Uzamış febril miyalji sendromu (UFMS), ailesel Akdeniz ateşinin (AAA) nadir görülen çarpıcı bir belirtisi olup, şiddetli miyalji ve yüksek ateş ile karakterizedir. Bu sendrom, AAA'nın kortikosteroid tedavisi gerektiren nadir bir vaskülit türü veya MEFV gen mutasyonları ile ilişkili olan inflamasyon uzantısı olarak kabul edilmektedir. Sendrom için kesin çevresel tetikleyiciler bilinmemesine rağmen, streptokok enfeksiyonları gibi olası çeşitli faktörler öne sürülmüştür. Bu yazıda, uzun süreli seyahat ve hipertermal $\left(>40{ }^{\circ} \mathrm{C}\right)$ balneoterapiden sonra UFMS gelişen 33 yaşında bir erkek olgu sunuldu. Bildiğimiz kadarıyla bu, UFMS ve balneoterapi arasında muhtemel bir ilişkiyi öneren ilk olgu sunumudur.

Anahtar sözcükler: Balneoterapi; ateş; miyalji.

to corticosteroids, ${ }^{[1-3]}$ and without this treatment, the symptoms last for four-six weeks. ${ }^{[3]}$ Patients are diagnosed with PFMS on the basis of the presence of these clinical and laboratory characteristics. In addition, it is known to be associated with Mediterranean Fever (MEFV) gene mutations; however, its environmental triggering mechanisms are unknown.

In this report, we present a patient who developed who was diagnosed with PFMS after long-duration

\footnotetext{
Received: November 05, 2012 Accepted: December 03, 2012

Correspondence: Mahmut Alpaycı, M.D. Bitlis Devlet Hastanesi Fizik Tedavi ve Rehabilitasyon Kliniği, 13000 Bitlis, Turkey. Tel: +90 505 - 7074114 e-mail: mahmutalpayci@gmail.com 
travel and hyperthermal $\left(>40{ }^{\circ} \mathrm{C}\right)$ balneotherapy, with the goal of drawing attention to the possible environmental triggers of this syndrome. To our knowledge, this is the first article that proposes a possible relationship between PFMS and balneotherapy.

\section{CASE REPORT}

A 33-year-old male patient was admitted to the emergency department of our hospital complaining of generalized, continuous, severe paralyzing myalgia, abdominal pain, and high fever (38.5$39.5{ }^{\circ} \mathrm{C}$ ) that had begin four days earlier. Due to the severe myalgia, he was unable to walk without help. A physical examination revealed diffuse muscular and abdominal tenderness, but there were no skin lesions on the patient nor was there lymph node enlargement. The chest X-ray and abdominal ultrasonography results were normal. The patient was hospitalized for observation in the general surgical ward, and conservative treatment that included intravenous antibiotics and analgesics was initiated. Laboratory analyses revealed leukocytosis $\left(13.940 / \mathrm{mm}^{3}\right)$ with neutrophil predominance $(82.2 \%)$ and thrombocytosis $\left(460.000 / \mathrm{mm}^{3}\right)$ along with normal eosinophil, rheumatoid factor (RF), and anti-streptolysin $\mathrm{O}$ (ASO) titer levels. The results for routine biochemical blood tests, including an evaluation of creatine kinase (CK) and transaminases, and urine tests were normal, and stool test results for parasites and occult blood were negative as well. The C-reactive protein (CRP), erythrocyte sedimentation rate (ESR), and fibrinogen levels were $51.94 \mathrm{mg} / \mathrm{L}, 36 \mathrm{~mm} / \mathrm{h}$, and $508 \mathrm{mg} / \mathrm{dL}$ respectively, and all were elevated. Furthermore, the serology for brucellosis, salmonellosis, hepatitis B virus, and hepatitis $\mathrm{C}$ virus was negative, and blood and throat cultures for the patient were sterile. On the fourth day of hospitalization, because of the ongoing paralyzing myalgia and high fever, the patient was referred to a physiatrist due to the suspicion of FMF. When the patient was questioned, he stated that his symptoms had begun after longduration travel and hyperthermal balneotherapy, and his previous medical history revealed typical FMF attacks, which can cause recurrent high fever and abdominal pain with spontaneous remission. Thus, the patient was diagnosed with FMF as well as PFMS, and methylprednisolone $(1 \mathrm{mg} / \mathrm{kg} /$ day) treatment was started. His symptoms then disappeared, and the acute-phase reactant levels declined rapidly, supporting the diagnosis of PFMS. Colchicine (1 mg/day) was added to the treatment, and the patient was gradually weaned from the methylprednisolone. A mutational analysis of the MEFV gene demonstrated heterozygous V726A mutation in exon 10, which confirmed the diagnoses of PFMS and FMF; hence, the colchicine treatment was continued. During the six-month follow-up period, the patient experienced none of previously described clinical episodes of FMF nor any new attacks of PFMS. In addition, the acutephase reactant levels remained within the normal range.

\section{DISCUSSION}

Protracted febrile myalgia syndrome is an extension of the inflammation associated with FMF or a rare form of vasculitis that is an FMF-specific manifestation characterized by severe paralyzing myalgia and high fever with normal CK levels but elevated CRP and ESR. ${ }^{[1,2]}$ Another noteworthy feature of PFMS is that the signs and symptoms dramatically respond to corticosteroids. ${ }^{[1-3]}$ These findings contribute significantly to the diagnosis of this syndrome, but a genetic analysis is still required to confirm the diagnosis. In addition to the clinical and laboratory features, our patient fulfilled other criteria with the presence of the MEFV mutation and his dramatic response to the corticosteroid treatment, both of which led to the diagnosis of PFMS and FMF.

Because PFMS may recur even with the colchicine prophylaxis, ${ }^{[3]}$ it is important to recognize the environmental triggers that cause this syndrome in order to prevent its occurrence. It is known that various MEFV mutations are associated with PFMS, but the specific mechanisms that precipitate this syndrome are unclear. Unlike previous reports in which most patients had a homozygous M694V mutation, ${ }^{[4,5]}$ our patient was heterozygous for the V726A mutation. Additionally, our patient was also different from some of the previously published cases $^{[3,6]}$ involving PFMS in terms of the possible environmental triggers. While long-duration travel and hyperthermal balneotherapy are the most likely causes of PFMS in our patient, diabetic ketoacidosis ${ }^{[6]}$ and streptococcal infections ${ }^{[3]}$ have been suggested in other cases. It is also possible that some factors might result in a change in the proinflammatory cytokine level, and these could also bring about the attacks. ${ }^{[7]}$ 
In a study by Karadağ et al. ${ }^{[8]}$ that investigated the potential causes of FMF attacks, they found a relationship between the MEFV mutations and the triggering factors in which the M694V allele was associated with starvation while the V726A allele was associated with long-duration travel. ${ }^{[8]}$ Similarly, our patient had traveled for a long period of time, and the V726A mutation was identified in his MEFV gene. However, in our review of the literature, we could not find any study that specifically focused on the potential triggering mechanisms of PFMS.

In our patient, the syndrome began about 16 hours after hyperthermal balneotherapy; hence, it is logical to conclude that this type of therapy might be a risk factor for PFMS. Because healthy heterozygotes for MEFV mutations have higher than normal acute-phase reactant levels, and many FMF patients continue to have subclinical inflammation during attack-free periods. ${ }^{[9]}$ Thus, the effect of the hyperthermal balneotherapy on our patient might have been increased due to his existing chronic inflammation. Furthermore, PFMS had already been considered to be an extension of FMF inflammation by Bircan and Usluer ${ }^{[2]}$

Familial Mediterranean fever attacks that coexist with thermal crisis, a side effect of balneotherapy, should be considered as a differential diagnosis. The clinical picture associated with thermal crisis can include local or general symptoms such as anorexia, sleep disturbances, irritability, hot and cold intolerance, changes in libido, limb paresthesia, muscle tone changes, tremors, and dermographism. ${ }^{[10]}$ However, none of these symptoms was evident in our patient.

In conclusion, depending on the different MEFV mutations, the triggering factors may be different in FMF. As was the case with our patient, long-duration travel and hyperthermal balneotherapy are possible environmental triggers for PFMS patients with the V726A mutation.

\section{Declaration of conflicting interests}

The authors declared no conflicts of interest with respect to the authorship and/or publication of this article.

\section{Funding}

The authors received no financial support for the research and/or authorship of this article.

\section{REFERENCES}

1. Gokçe I, Demirkaya E, Gok F. Protracted febrile myalgia in a child as the presenting sign of familial Mediterranean fever: case report and review of the literature. Balkan Med J 2011;28:222-3.

2. Bircan Z, Usluer H. Protracted febrile myalgia mimicking polyarteritis nodosa. J Clin Rheumatol 2008;14:222-5.

3. Soylu A, Kasap B, Türkmen M, Saylam GS, Kavukçu S. Febrile myalgia syndrome in familial Mediterranean fever. J Clin Rheumatol 2006;12:93-6.

4. Kaplan E, Mukamel M, Barash J, Brik R, Padeh S, Berkun $\mathrm{Y}$, et al. Protracted febrile myalgia in children and young adults with familial Mediterranean fever: analysis of 15 patients and suggested criteria for working diagnosis. Clin Exp Rheumatol 2007;25:S114-7.

5. Sidi G, Shinar Y, Livneh A, Langevitz P, Pras M, Pras E. Protracted febrile myalgia of familial Mediterranean fever. Mutation analysis and clinical correlations. Scand J Rheumatol 2000;29:174-6.

6. Demir K, Carman KB, Kasap B. Concurrent protracted febrile myalgia syndrome in a child with diabetic ketoacidosis. Pediatr Diabetes 2012;13:510-3.

7. Solak Y, Atalay H, Polat I, Biyık Z, Gaipov A, Kucuk A, et al. A Case of Familial Mediterranean Fever After Renal Transplantation: From Phenotype II to I. Turk J Rheumatol 2012;27:140-3.

8. Karadag O, Tufan A, Yazisiz V, Ureten K, Yilmaz S, Cinar $\mathrm{M}$, et al. The factors considered as trigger for the attacks in patients with familial Mediterranean fever. Rheumatol Int 2013;33:893-7.

9. Alpayci M, Bozan N, Erdem S, Gunes M, Erden M. The possible underlying pathophysiological mechanisms for development of multiple sclerosis in familial Mediterranean fever. Med Hypotheses 2012;78:717-20.

10. Karatas M. Balneotherapy. In: Oguz H, Dursun E, Dursun $\mathrm{N}$, editors. Medical rehabilitation. 2nd ed. İstanbul: Nobel Kitapevi; 2004. s. 355-62. 